\title{
PEMBERDAYAAN IBU RUMAH TANGGA MELALUI PELATIHAN MEMBUAT HANTARAN PERNIKAHAN MELAYU MOTIF SATWA
}

\author{
Latifa Siswati $^{* 1}$, Surtinah Surtinah ${ }^{2}$, Rini Nizar ${ }^{3}$ \\ ${ }^{1,2,3}$ Proram Studi Agribisnis, ${ }^{2}$ Program Studi Agroteknologi \\ Fakultas Pertanian, Universitas Lancang Kuning \\ *E-mail: latifasiswati@unilak.ac.id
}

\begin{abstract}
Wedding delivery is a symbol of the prestige of the bridegroom, and this activity is carried out before the wedding takes place. Marriage delivery in the form of goods needed in the household in the form of clothing, prayer equipment, toiletries, and beauty equipment. This activity was carried out in the Salimah study group. The method used is awareness, demonstration, and trial. The results obtained from this activity are that participants understand how to make wedding deliveries from towels by 100\%. Participants understand and are able to make wedding deliveries from towels and also understand the stages as much as $100 \%$. The service participants succeeded in making a wedding delivery from a towel.
\end{abstract}

Keywords - Wedding, Delivery, Towel

\begin{abstract}
Abstrak
Hantaran pernikahan merupakan symbol prestise pengantin laki-laki, dan kegiatan ini dilakukan sebelum acara pernikahan berlangsung. Hantaran pernikahan berupa barang barang yang dibutuhkan dalam berumahtangga yang berupa pakaian, perlengkapan sholat, perlengkapan mandi, dan perlengkapan kecantikan. Kegiatan ini dilakukan di kelompok pengajian Salimah. Metode yang digunakan adalah penyadaran, demontrasi, dan uji coba. Hasil yang diperoleh dari kegiatan ini adalah Peserta mengerti bagaimana membuat hantaran pernikahan dari handuk sebesar 100\%. Peserta mengerti dan mampu membuat hantaran pernikahan dari handuk dan juga memahami tahapan-tahapannya sebanyak 100\%. Peserta pengabdian berhasil membuatn hantaran pernikahan dari handuk.
\end{abstract}

Kata kunci-Pernikahan, Hantaran, Handuk

\section{PENDAHULUAN}

Hantaran pernikahan ini menjadi simbol prestise dari mempelai laki -laki yang meminang perempuan yang akan dinikahi (Huda, 2015) . Pada umumnya hantaran pernikahan yang diberikan kepada perempuan yang akan dijadikan istrinya adalah hantaran di daerah melayu khususnya Riau berupa perlengakapan solat, slimut, seperangkat pakaian perempuan siap pakai yang dibeli di pasar (Syahrani \& Fatimah, 2015). Dan untuk hantaran pernikahan ini mempelai laki-laki akan menyediakan anggaran sendiri, tergantung kondisi keuangan dari penyelenggaran laki-laki tersebut. Kondisi tersebutlah yang menjadi dasar pemikiran dilaksanakannya pelatihan membuat souvenir pernikahan ini. Dengan memberdayakan ibu-ibu rumahtangga yang memiliki banyak waktu luang di rumah, untuk dapat memnafaatkan waktu tersebut menghasilkan suatu karya yang dapat digunakan untuk menambah penghasilan keluarga.

Ibu-ibu di Kelurahan Rumbai tergabung dalam kelompok wirid Pengajian. Tujuan dari organisasi ini adalah membuat anggota pengajian selain mempelajari ilmu agama juga mampu untuk menghasilkan produk yang dapat meningkatkan taraf hidup mereka (Surtinah \& Nizar, 2017). Namun pada kenyataannya organisasi ini hanya sebuah formalitas saja, karena banyak anggota justru tidak berdaya dengan kondisi mereka dalam mengangkat taraf hidup keluarganya.Melalui kegiatan ini Tim pengabdian ingin menyumbangkan sedikit pengetahuan yang dirasa mampu untuk meningkatkan penghasilan keluarga dengan memberikan sedikit ketrampilan kepada ibu-ibu tersebut, sekaligus untuk mencapai visi Unilak, yaitu menjadi 
universitas unggul di tingkat nasional berlandaskan budaya melaytu tahun 2030. Permasalahan yang dihadapi oleh mitra adalah rendahnya pengetahuan tentang cara membuat hantaran pernikahan melayu dengan motif satwa, belum adanya pelatihan tentang ktrampilan membuat hantaran pernikahan melayu dengan motif satwa, kKeraguan terhadap kemampuan diri sendiri dalam membuat hantaran pernikahanMelayu Riau. Untuk mengatasi permasalahan tersebut maka Tim menyusun cara dalam melaksanakan kegiatan tersebut, antara lain peningkatan pengetahuan tentang manfaat membuat hantaran motif satwa, memberikan pelatihan cara membuat hantaran pernikahan melayu dengan motif satwa, dan praktek langsung yang dilakukan peserta untuk membuat sendiri hantaran dari saputangan handuk.

\section{METODE}

Metode yang akan dilaksanakan untuk mencapai tujuan adalah dengan penyadaran untuk eningkatkan pengetahuan tentang hantaran pernikahan yang dihubungkan dengan ekonomi keluarga, demontrasi atau Memberikan pelatihan cara melipat seperei, mukena, dan handuk untuk dijadikan hantaran pernikahan yang bernilai jual, dan uji coba: kegiatan yang dilakukan dengan memberi kesempatan kepada peserta untuk membuat secara langsung hantaran

\section{HASIL DAN PEMBAHASAN}

Kegiatan Pelatihan Pembuatan Hantaran pernikahan di Kelurahan Rumbai Kota Pekanbaru, Kegiatan Pengabdian kepada Masyarakat ini dilaksanakan di kediaman salah satu anggota Pengajian Salimah Rumbai.Undangan yang hadir merupakan anggota pengajian Salimah yang terdiri dari ibu-ibu rumah tangga. Peserta yang datang untuk mengikuti pelatihan ini sebanyak 32 orang

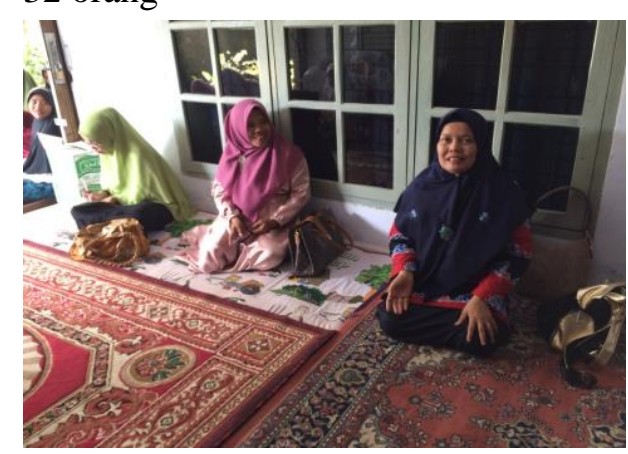

Gambar 1. Ketua Tim Memberikan Pelatihan Membuat Hantaran Melayu

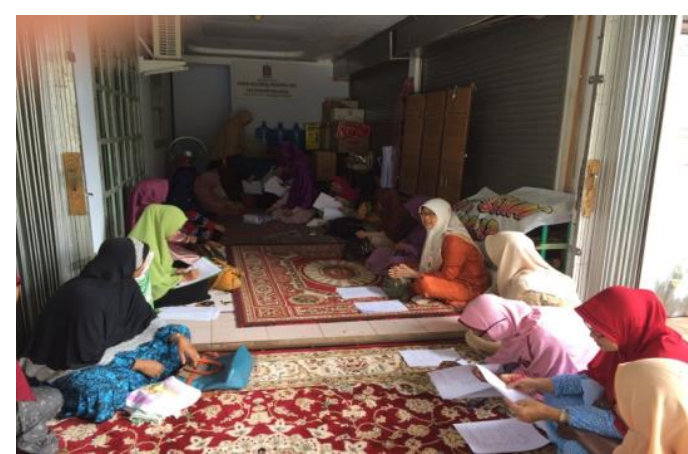

Gambar 2. Peserta Pelatihan sedang Mengisi Kuisioner

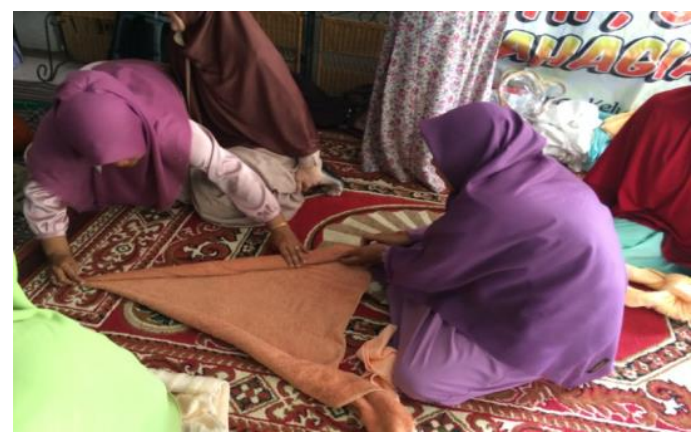

Gambar 3. Peserta Pelatihan sedang mempraktekan Membuat Hantaran 

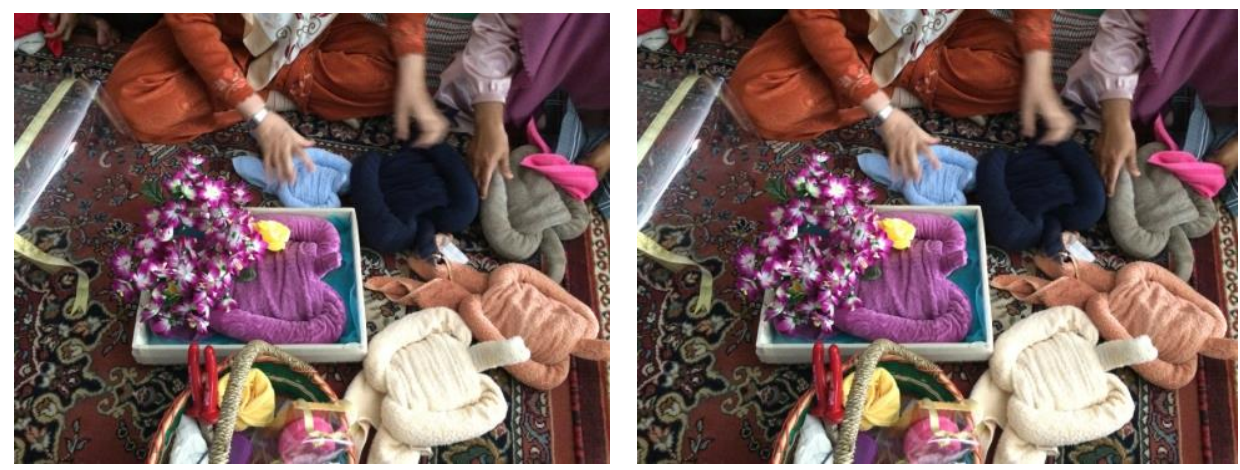

Gambar 4. Hasil Pelatihan Membuat hantaran Motif Kura -kura
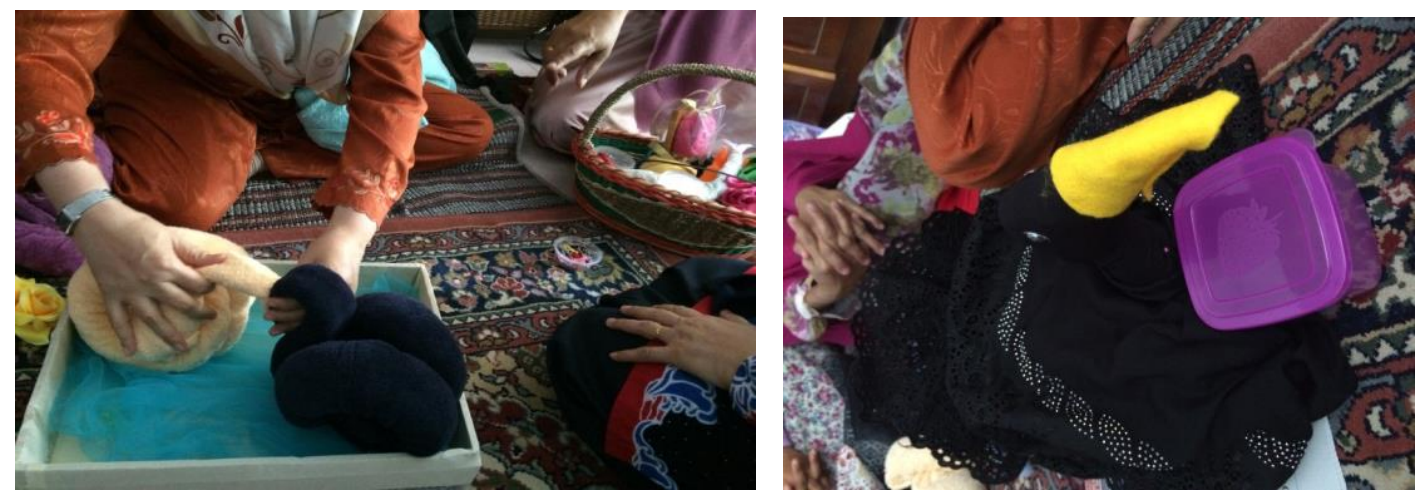

Gambar 5. Hantaran Motif Burung

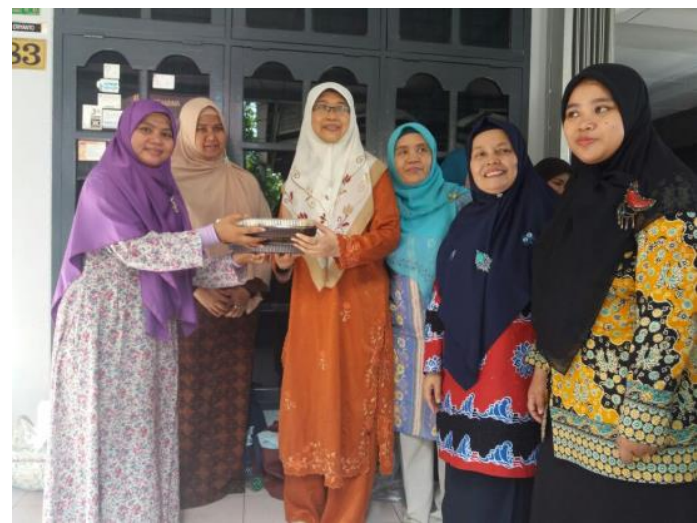

Gambar 6. Ketua Pengajian Salimah Menyerahkan produk Kelompok

Pelaksanaan kegiatan pelatihan diawali dengan pre test, semua peserta yang hadir yaitu sebanyak 32 orang ikut berpartisipasi dalam mengerjakan pre test yang dibagikan kepada masingmasing peserta. Kemudian dilanjutkan dengan materi penyuluhan yaitumengenaikeunggulanataumanfaat yang didapatdaripelatihan pembuatan hantran pernikahan dari bahan handuk. Peserta cukup antusias dalam mengikuti pelatihan yang dilakukan, dilihat dari perhatian dan banyaknya pertanyaan yang diajukan oleh peserta. Dari pertanyaan dan hasil diskusi pada umumnya peserta merasa bermanfaat sekali materi yang diajarkan, karena bahan yang digunakan untuk pembuatan hantaran mudah didapatkan dan harga belinya pun murah, selain itu juga dibandingkan apabila membeli hantaran yang sudah jadi lebih mahal harganya dibanding dengan membuat. Setelah kegiatan penyuluhan dan diskusi dilanjutkan dengan kegiatan demo bagaimana pembuatan hantaran pernikahan tersebut, dan kegiatan dilanjutkan dengan post test dengan tujuan mengetahui sejauh mana progres pengetahuan peserta bertambah.Post Test ini diikuti oleh semua peserta pelatihan sebanyak 32 orang. Hasil Pre Test dan Post Test yang telah 
dilaksanakan untuk mengukur tingkat pengetahuan peserta tentang membuat hantaran pernikahan dari bahan handuk, dan mukena.

Setelah kegiatan penyuluhan, diskusi dan demo kegiatan dilanjutkan dengan post test dengan tujuan mengetahui sejauh mana progres pengetahuan peserta bertambah.Post Test ini diikuti oleh semua peserta pelatihan sebanyak 32 orang. Hasil Pre Test dan Post Test yang telah dilaksanakan untuk mengukur tingkat pengetahuan peserta tentang Membuat hantaran pernikahan dari bahan handuk, dan mukena dapat dilihat pada Gambar 7 dibawah ini.

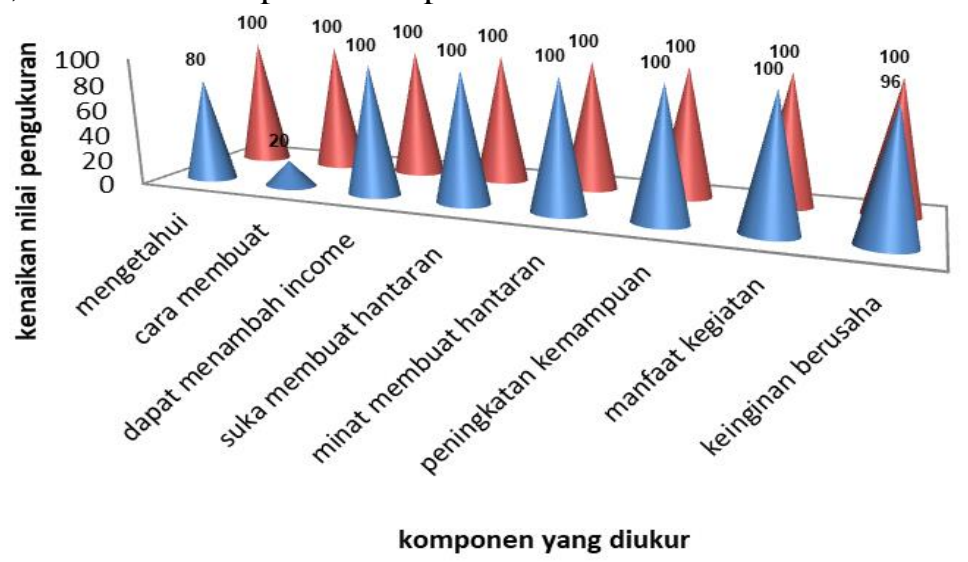

Gambar 7. Hasil Kuisioner Pre Test dan Post Test pilihan jawaban Ya dan Tidak

Evaluasi berdasarkan jawaban peserta berupa hasil Pre Test dan Post Test dengan jawaban ya dan tidak dapat dijelaskan bahwa pengetahuan peserta mengenai pembuatan hantaran pernikahan dari handuk meningkat cukup signifikan dari hanya $80 \%$ ketika Pre Test meningkat menjadi $100 \%$ artinya peningkatan pengetahuan peserta tentang pembuatan souvenir pernikahan dari saputangan sangat baik,begitu juga dengan pengetahuan mengenai cara pembuatan hantaran pernikahan dari handuk meningkat secara signifikan dari Pre Test $20 \%$ menjadi $100 \%$ pada saat Post Test. Peserta ternyata sebelumnya tidak mengetahui bagaimana cara pembuatan hantaran pernikahan dari handuk, dan mukena setelah dilakukan demo pembuatan hantaran pernikahan dari handuk dan mukena tanggapan peserta terhadap bahan yang dibutuhkan ternyata mudah diperoleh dan cara pembuatannya pun gampang. Untuk pertanyaan apakah peserta mengetahui bahwa membuat hantaran pernikahan dari handuk dapat menambah penghasilan keluarga ternyata pada saat pre test hanya sedikit peserta yang tahu apa saja bahan yang dibutuhkan itu terbukti dari jawaban yang menjawab ya hanya $10 \%$ sedangkan yang menjawab tidak sebanyak $90 \%$. Tetapi pada saat post test ternyata mengalami peningkatan sebanyak $100 \%$, itu membuktikan bahwa peserta setelah diberikan informasi menangkap apa informasi yang diberikan.

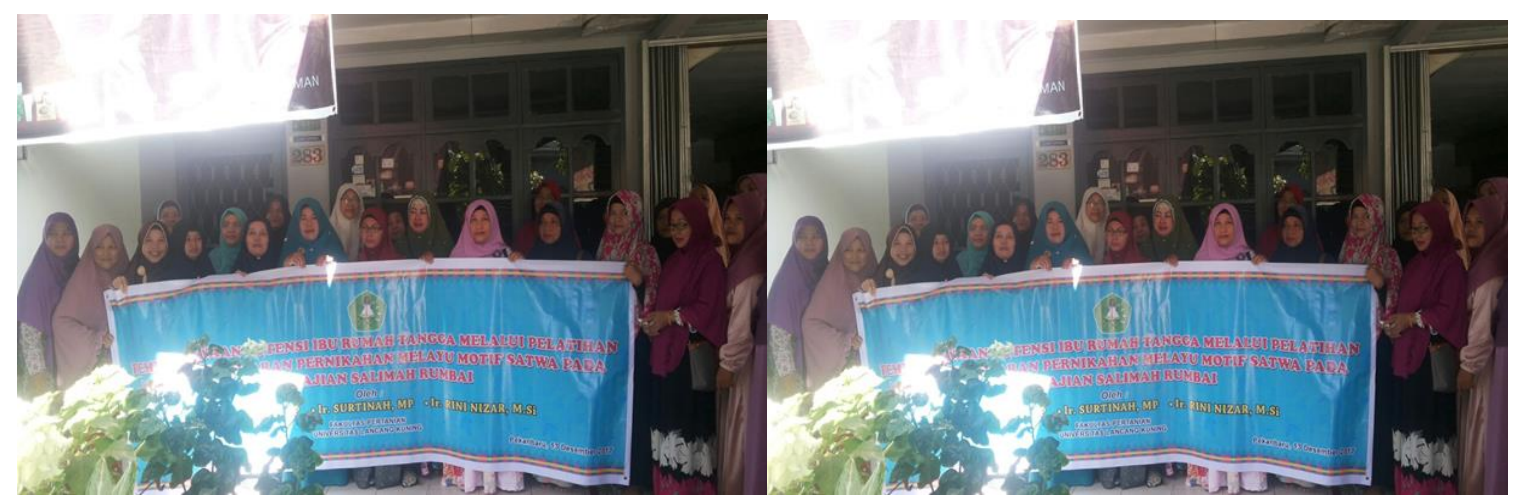

Gambar 8. Foto Bersama Setelah Pelatihan

Pernyataan ke delapan dari pre test diperoleh bahwa ada 4 (empat) orang peserta yang tidak ingin membuat hantaran pernikahan, tetapi dari hasil post test diperoleh hasil bahwa keempat 
peserta yang tadinya tidak berminat untuk membuat hantaran pernikahan, setelah menerima pelatihan cara membuat hantaran pernikahan menjadi tertarik untuk membuat hantaran pernikahan. Hal ini disebabkan karena mudahnya dalam membuat hantaran pernikahan, dan bila hantaran pernikahan ini dijadikan ketrampilan bagi kelompok ibu-ibu "Salimah" maka akan menambah uang kas kelompok.

Setiap satu set hantaran pengantin melayu, upah yang dapat diterima adalah Rp. 375.000,sampai dengan Rp. 500.000,- tergantung seberapa banyak jenis hantaran yang akan dibuat. Dan diketahui bahwa setiap anggota kelompok memiliki anggota keluarga yang bakal menikah, dan setiap pernikahan selalui diawali dengan prosesi lamaran, hantaran dan lain-lain, sesuai dengan yang dilaporkan oleh (Syahrani \& Fatimah, 2015), bahwa pernikahan merupakan sunah Rasul dan prosesi pernikahan merupakan kebudayaan yang tidak melanggar syari'ah agama. Oleh karena itu ketrampilan ini memiliki peluang yang besar untuk dikembangkan, terutama dikalangan kelompok pengajian "Salimah".

Surtinah, Amelia, \& Putri, (2018), melaporkan bahwa dengan menerima pesanan souvenir pengantin per 100 buah yang dikemas dalam kotak diperoleh keuntungan sebesar Rp. 134.000,yang dikerjakan dalam waktu 4 jam, sedangkan bila kemasan diganti dengan menggunakan bungkus plastic maka keuntungan yang akan diperoleh menjadi Rp. 203.400,- dengan waktu yang sama yaitu 4 jam. Hal ini tidak menutup kemungkinan bahwa kegiatan pembuatan hantaran dari bahan handuk juga akan memperoleh keuntungan sebagai bentuk nilai tambah dari kegiatan yang dilakukan di rumah oleh kelompok pengajian "Salimah" Rumbai.

\section{KESIMPULAN}

Kegiatan pengabdian kepada masyarakat yang telah dilaksanakan di Kelurahan Rumbai dapat meningkatkan pengetahuan dan membuka wawasan peserta hantaran pernikahan dari saputangan tentang baik cara pembuatan, bahan yang digunakan. Adapun peningkatan sesuai target sebagai berikut:

1. Peserta mengerti bagaimana membuat hantaran pernikahan dari saputangan sebesar $100 \%$.

2. Peserta mengerti dan mampu membuat hantaran pernikahan dari saputangan dan juga memahami tahapan-tahapannya sebanyak $100 \%$

3. Peserta pengabdian ikut mempraktekan pembuatan hantaran pernikahan dari saputangan

\section{SARAN}

Saran pada pengabdian kepada masyarakat yang telah dilakukan adalah masyarakat lebih diberikan pelatihan lanjutan untuk membuat hantaran pernikahan dari bahan yang murah,dan mudah didapat, karena dengan kegitan tersebut dapat meningkatkan atau menambah pendapatan keluarga selain itu juga dapat, memanfaatkan waktu luang yang dimiliki oleh ibu rumah tangga dengan kegiatan yang bermutu

\section{UCAPAN TERIMA KASIH}

Terimakasih tim aturkan kepada Universitas Lancang Kuning yang telah mendanai kegiatan pengabdian kepada masyarakat ini. Terimaksih kepada ibu Rektor yang telah memvasilitasi penegabdian kepada masyarakat ini, juga ucapan terimaksih kepada tim Lembaga penelitian dan Pengabdian pada Masyarakat Universitas Lancang Kuning, Serta ibu dekan Fakultas Pertanian .

\section{DAFTAR PUSTAKA}

[1] Huda, N. (2015). Analisis Gender "Baantaran Jujuran" Dalam Kebudayaan Banjar. J. Muadallah, 2(2). 
DINAMISIA - Jurnal Pengabdian Kepada Masyarakat Vol. 2, No. 2 Desember 2018, Hal. 205-210

[2] Surtinah, S., Amelia, V., \& Putri, A. (2018). MODIFIKASI SAPUTANGAN MENJADI BENTUK PRODUK PERTANIAN UNTUK SOUVENIR PENGANTIN MELAYU DI KELURAHAN RUMBAI. JURNAL PENGABDIAN KEPADA MASYARAKAT, 24(2), 623-628.

[3] Surtinah, S., \& Nizar, R. (2017). PEMANFATAN PEKARANGAN SEMPIT DENGAN HIDROPONIK SEDERHANA DI PEKANBARU. JURNAL PENGABDIAN KEPADA MASYARAKAT, 23(2), 274-278.

[4] Syahrani, R. P., \& Fatimah, N. (2015). Tunjuk Ajar Melayu Dalam Pantun Adat Perkawinan Melayu Kelurahan Daik Kabupaten Lingga Provinsi Kepulauan Riau. 